\title{
Begonia roxburghii: A potentially important medicinal plant
}

\author{
Lucy Lalawmpuii* and Lalbiakngheti Tlau \\ Department of Life Sciences, Pachhunga University College, Mizoram University, Aizawl 796001, Mizoram
}

\begin{abstract}
Begonia roxburghii is an annual dicot plant of the family Begoniaceae and is found in tropical and subtropical regions of the world. They are monoecious (has both male and female organs) and they are generally self-pollinated. Its parts are variously used in traditional practice for different health benefits. The stem is a nutritious snack, the juice is antihaemorrhoid and antiinfectious agent. It is used for the treatment of bee sting, skin infection, dysentery, diarrhoea, gastric ulcer, oral infection, jaundice and diabetes mellitus. It is chemically rich in flavonoids, alkaloids, glycosides, tannins, saponins, reducing sugars, steroids, resins, carbohydrates and phenols. It is shown to have high antioxidant activity as well as antimicrobial activity. However, little is known about the actual bioactive components and their effects on various health conditions related to its medicinal applications. This plant, therefore, has a potential for medicinal value for a wide array of diseases and clinical conditions, and would be worth systematic chemical and pharmacological characterizations.
\end{abstract}

Keywords: Begonia roxburghii, traditional medicine, phytocompounds, morphology. Received 12 January 2021
Accepted 15 February 2021
*For correspondence:
lucykjhaznich@gmail.com
Contact us:
sciencevision@outlook.com

\section{Introduction}

Begonia roxburghii (Miq.) A.DC. belongs to the family Begoniaceae. It is an annual dicot herb widely distributed in the shady moist places of tropical and subtropical regions of the world. Begnonia is an interesting genus with about 900 recognized species described from Asia where 45 species are reported from India. ${ }^{1}$ They are most abundant in equatorial countries in and around Southeast Asia; and are also found in other parts of Asia, Africa, Central and South America. ${ }^{2}$ The first publication found on Begonia was published by Spanish physician Francisco Hernandez in $1651 .^{3}$ The genus name Begonia was given by French botanist Charles Plumier, ${ }^{3}$ and the plants are commonly known by the genus name itself, "begonia".
Begonia is the fifth-largest angiosperm genera of flowering plants. ${ }^{4} \mathrm{~A}$ majority of the species are perennial herbs, rarely annual, some climbing with succulent stems and thick rhizomes or tubers. The leaves are usually simple but may be compound in some species and are commonly asymmetrical with their one side much larger than the other. Most species are usually monoecious with flowers of both sexes developing on the same plant, the flowers are unisexual. ${ }^{5}$ Many species and hybrids of Begonia are cultivated as ornamentals and grown indoors in cooler climates. B. roxburghii is traditionally used as medicinal plant by different tribes in northeast India for different health-related issues. Many folk medicinal practitioners used medicinal plants directly 
as primary health care therapeutics. ${ }^{6,7}$ These uses have been translated effectively to pharmaceutical drugs which suggests that this plant is also an interesting species because of its versatile applications. The leaves and whole plant are locally used as ingredients in soup. It contains important secondary metabolites and nutrients such as tannins, alkaloids, flavonoids, glycosides, saponins and carbohydrates, ${ }^{8}$ which provide definite pharmacological actions for the human body.

\section{Taxonomical classification}

$\begin{array}{ll}\text { Kingdom } & \text { : Plantae } \\ \text { Division } & : \text { Angiosperms } \\ \text { Class } & : \text { Magnoliopsida } \\ \text { Order } & : \text { Cucurbitales } \\ \text { Family } & : \text { Begoniaceae } \\ \text { Genus } & : \text { Begonia } \\ \text { Species } & : \text { roxburghii } \\ \text { Botanical Name } & : \text { Begonia roxburghii (Miq.) DC. }\end{array}$

\section{Geographical Distribution}

The species Begonia roxburghii is widely distributed in Eastern Himalaya, Nepal, Bangladesh, West Himalaya, Assam and Myanmar. The genus Begonia is pantropically distributed, with the exception of tropical Australia, ${ }^{1}$ and is most abundant in Southeast Asia. It has been found that this species of Begonia is also known to occur abundantly in Eastern Himalayas particularly in northeast India, Nepal and Indo-China region. ${ }^{9}$ It grows readily on moist and shady places, some in sunny places but fewer in flowers, uncultivated areas, shady fertile soil of primary forest and shaded places along the stream.

\section{Propagation}

B. roxburghii (Figure 1) is an annual growing plant that grows up to $80 \mathrm{~cm}$ tall. It flowers from February to October and fruiting from July to October. ${ }^{10}$ The species is monoecious (has both male and female organs) and they are generally self-pollinated. It can grow in semi-shaded light and can be found easily around waterfalls and watery habitats. It can grow from the seed present at the end of the stem when the flowers are about to die. The seeds can produce several numbers of young plants if they are viable. These seeds may germinate readily after falling to the ground. Apart from seed growing, begonias can be propagated through stem and leaf cutting by rooting in water, but leaf sections require sterile conditions. Most rhizomes can be rooted directly without any special considerations. Long rhizomes can even be rooted in water like stem cutting. They are slightly more prone to rotting in water though they are fleshy and can give rise to new plants faster. Apart from this particular species of begonia experiment were performed in species like Begonia venosa propagated through inflorescence, ${ }^{11}$ Begonia tuberhybrida in vitro propagation from leaf sections, ${ }^{12}$ and many more. In Eliator begonias plant breeding has been experimentally demonstrated and different disease resistant varieties have been produced. $^{13}$ These experiments were done to improved disease controlled and more production of important ornamentals begonias and maintain the integrity of the plant breeds.

\section{Morphological characters}

The stem of $B$. roxburghii is erect with distinct nodes and internodes dotted with red streaks (Figure 1A), often branched usually 40-200 cm long. ${ }^{14}$ Leaves are simple and opposite, 3-8 inches long and 1-5 inches broad at the unequal base, asymmetrical, pointed apex acute to nearly acuminate, margins obscurely serrate, minutely pubescent on both surfaces on veins, densely pubescent in young leaves and secondary nerves 7-9 pairs (Figure 1B). Stipules are 0.5-0.7 inches long, lanceolate and deciduous, ${ }^{15}$ while petioles are 0.9-2.5
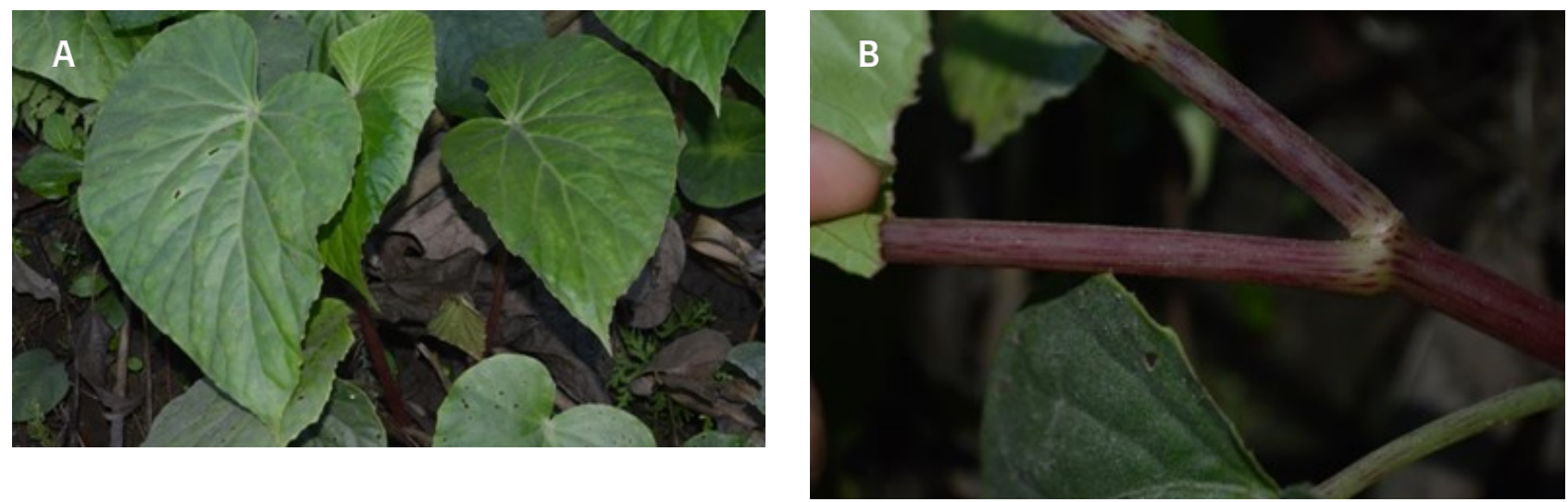

Figure 1 | Begonia roxburghii. A. Leaves. B. Stem 
inches long. The inflorescence is typically cymose and peduncled. Peduncles are axillary, red or pink with cymes few-flowered, dichotomous and bracts persistent. Male flower consists of two sepals and two petals. Stamens are about 40-50 yellow in colour which are clustered in bundles at the center. Female flowers have 4-5 sepals in numbers covered by minute hairs, oval to oblong in shape. Styles are four in number, twisted twice and persistent. Stigma branched, ovary quadrangular, pyramidal, fourcelled, fleshy, wingless and minutely horn-like projections, placentae usually divided twice. The fruit is four-lobed capsule 1-2 cm in diameter, covered with red dots and square in shape. Seeds are ellipsoid. ${ }^{16}$

\section{Phytochemistry}

The phytochemical constituents of $B$. roxburghii were extracted from the collection of leaves by standard procedures, ${ }^{17}$ and showed the presence of flavonoids, alkaloids, glycosides, tannins, saponins, reducing sugars, steroids, resins, carbohydrates and phenols. The extraction of secondary phytochemical constituents revealed that flavonoids and alkaloids are present in a very high concentration ${ }^{8,18}$ while other substances are present in average amount. The methanolic extract from the leaf of $B$. roxburghii showed considerable amount of percent inhibition against DPPH free radical, total phenolic content (TPC), total flavonoid content (TFC) and total antioxidant capacity (TAC) indicating a strong antioxidant potential of the plant. The methanolic extract is also used for different test which show the activities of cytotoxic potential, analgesic, antiarthritis and thrombolytic. In similar studies of different species, experiments had been carried out on other species of begonia in which phytochemical analysis of $B$. trichocarpa shows the presence of flavonoids, steroids, lipids, carbohydrates, amino acids, coumarins and oxalic acids and also possess significant antimicrobial activity. ${ }^{19}$ The aqueous extract of Begonia malabarica show antibacterial activity against Gram-negative bacteria except Vibrio parahaemolyticu and antimicrobial activity. ${ }^{20}$

\section{Ethnomedicinal Uses}

B. roxburghii is used in different traditional medicines, some of which are as follows:

1. The juice of the plant is used for the treatment of skin problem and piles (haemorrhoids). The stem is eaten raw as wild snack by children.

2. The leaves and stem provide effectives remedy for the treatment of bee stink and stomachache. ${ }^{21}$

3. The whole plant is effective in gastrointestinal disorders like diarrhea, bile dysentery, stomach ulcer and stomachache. ${ }^{22}$

4. The leaves and roots of $B$. roxburghii are widely used in the treatment of tongue abnormalities, diarrhea, dysentery and jaundice. ${ }^{23}$

5. The fresh leave juice extract is directly consumed for management of diabetes. ${ }^{24}$

6. The rhizome or bulb provides effective remedy against thorn stuck in the body and prevent infection.

\section{Conclusion}

It is concluded from this review that Begonia roxburghii is unique source of metabolites such as flavonoids, alkaloids, glycosides, tannins, saponins which are obtained from crude extract of the plants. Investigation shows that the plant possesses antioxidant potential, analgesic, thrombolytic, antiarthritis and cytotoxic activity. Ethnobotanical uses of $B$. roxburghii has wide range in northeast India. Isolation of bioactive compounds has not been done yet from this particular plant but some phytochemical compounds were already isolated from different species of the same family. Further investigation on the pharmacological activities may be very challenging for the development of useful and less toxic natural based drugs.

\section{Conflict of interest}

The authors declared no conflict of interest.

\section{References}

1. Rajbhandary S, Hughes M, Shrestha KK. Distribution patterns of Begonia species in the Nepal Himalaya. Botanica Orientalis: Journal of Plant Science. 2010; 7:73-78.

2. Suresh M, Irulandi K, Siva V, Mehalingam P. A short review on ethnomedicinal uses, phytochemistry and pharmacology of Begonia malabarica Lam. International Journal of Science and Technology. 2009; 3(02):261-268.

3. Anderson NO, editor. Flower Breeding and Genetics: Issues, Challenges and Opportunities for the 21st Century. Springer Science \& Business Media; 2006.

4. Thorat R Bapu, K Sabiha, Jadhav D, Mrunali M. A review on phytochemistry and pharmacology of Begonia malabarica Lam. Asian Journal of Research in Pharmaceutical Sciences. 2018; 6(1): 6-15.

5. Neale S, Goodall-Copestake W, Kidner CA. The evolution of diversity in Begonia. Floriculture, Ornamental and Plant Biotechnology. 2006.

6. Ansari P, Uddin MJ, Rahman MM, AbdullahAlMamun M, Islam MR, Ali MH, Reza AS. Antiinflammatory, anti-diarrheal, thrombolytic and cytotoxic activities of an ornamental medicinal 
plant: Persicaria orientalis. Journal of Basic and Clinical Physiology and Pharmacology. 2017; 28 (1): 51-58.

7. Hossain MS, Reza AA, Rahaman MM, Nasrin MS, Rahat MRU, Islam MR, Uddin MJ, Rahman MA: Evaluation of morning glory (Jacquemontia tamnifolia (L.) Griseb) leaves for antioxidant, antinociceptive, anticoagulant and cytotoxic activities. Journal of Basic and Clinical Physiology and Pharmacology. 2018; 29(3):291-299.

8. Mobarak H, Meah MS, Sikder N, Tareq M, Azad A, Khatun R, Nasrin MS, Raihan MO, Reza AA. Investigation of preliminary phytochemicals, analgesic, anti-arthritic, thrombolytic and cytotoxic activities of Begonia Roxburghii (Miq.) DC. leaves. Med One. 2018; 3(1): e180001.

9. Flowers of India. East Himalayan Begonia. Available from: https://www.flowersofindia.net/ catalog/slides/East\%20Himalayan\% 20Begonia.html

10. Camfield R, Hughes M. A revision and one new species of Begonia L. (Begoniaceae, Cucurbitales) in Northeast India. European Journal of Taxonomy. 2018; 19(396). DOI 10.5852/ejt.2018.396

11. Pierik RL, Tetteroo FA. Vegetative propagation of Begonia venosa Skan in vitro from inflorescence explants. Plant Cell, Tissue and Organ Culture. 1987;10(2):135-142.

12. Peck DE, Cumming BG. In vitro propagation of Begonia tuberhybrida from leaf sections. HortScience. 1984;19(3):395-397.

13. Horn W. Breeding methods and breeding research. In A, Vainstain (ed), Breeding for Ornamentals: Classical and Molecular Approaches. Kluwer Academic Publications, Dortrecht. (2002), pp. 47-83.

14. Hughes M. \& Girmansyah D. A revision of Begonia sect. Sphenanthera (Hassk.) Warb. (Begoniaceae) from Sumatra. Garden's Bulletin Singapore. 2011. 62 (2): 239-251.
15. Clarke C.B. 1879. Begoniaceae. In: Hooker J.D. (ed.) Flora of British India 2: 636-656. London.

16. India Biodiversity Portal. Begonia roxburghii (Miq.) A.DC. Available from: https:// indiabiodiversity.org/species/show/228905

17. Tiwari P, Kumar B, Kaur M, Kaur G, Kaur H. Phytochemical screening and extraction: a review. International Pharmaceutical Science. 2011; 1(1): 98106.

18. Chowdhury FA. Investigation of in-vitro antioxidant and cytotoxic potential of methanol extract of Begonia roxburghii leaves. Department of Pharmacy Dhaka, Bangladesh. 2017.

19. Jose S, Siva Kumar T. Preliminary studies on phytochemical properties and antimicrobial activity of Begonia trichocarpa. International Journal of Research in Ayurveda and Pharmacy. 2016;7(5):9196.

20. Ramesh N, Viswanathan M B, Saraswathy A, Balakrishna K, Brindha P and Lakshmanaperumalasamy P. Phytochemical and antimicrobial studies of Begonia Malabarica. Journal of Ethnopharmacology, 79(1), 2002:129-132.

21. Tangjang S, Namsa ND, Aran C, Litin A. An ethnobotanical survey of medicinal plants in the Eastern Himalayan zone of Arunachal Pradesh, India. Journal of Ethnopharmacology. 2011 8;134(1):18 -25 .

22. Sawmliana, M. The Book of Mizoram Plants. Lois Bet, Chanmari, Aizawl, Mizoram. 2013.

23. Rahman M. Diversity, ecology and ethnobotany of the Zingiberaceae of Bangladesh. Journal of Economic and Taxonomic Botany Addl Series. 1996; 12:13-19.

24. Tag H, Kalita P, Dwivedi P, Das A, Namsa ND. Herbal medicines used in the treatment of diabetes mellitus in Arunachal Himalaya, northeast, India. Journal of Ethnopharmacology, 2012; 141(3): 786795. 